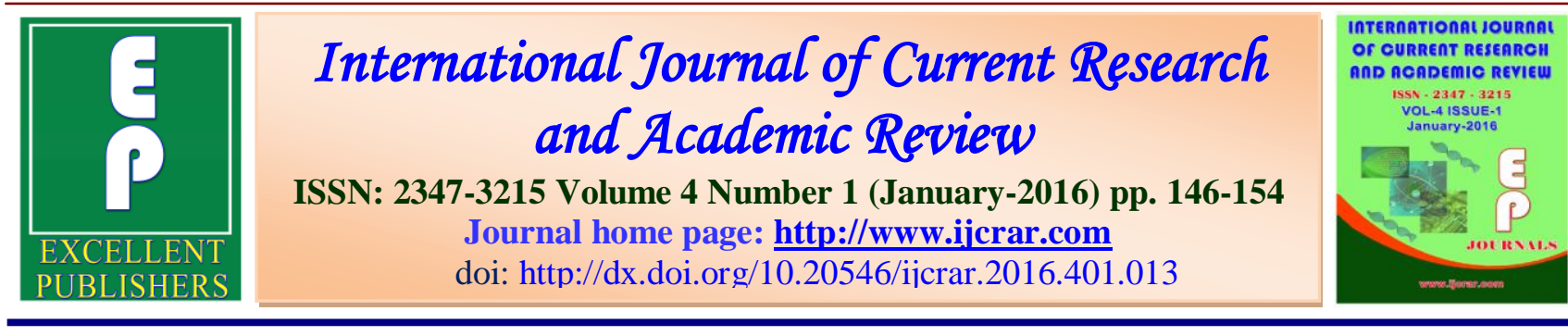

\title{
Optimizing Saccharification of Barley Malt by Response Surface Methodology
}

\author{
Naveet *and R.P. Phutela
}

Department of Microbiology, Punjab Agricultural University, Ludhiana-141004, India

*Corresponding author

\begin{tabular}{|c|c|}
\hline KEYWORDS & A B S T R A C T \\
\hline $\begin{array}{l}\text { Saccharification of } \\
\text { Barley Malt, } \\
\text { Saccharifying } \\
\text { enzymes, } \\
\text { catalysed starch } \\
\text { hydrolysis }\end{array}$ & $\begin{array}{l}\text { Barley malt has its own saccharifying enzymes whose activity and stability } \\
\text { was characterized at varying } \mathrm{pH} \text {, temperature and substrate concentration. } \\
\text { The response surface methodology (RSM) two level full factorial central } \\
\text { composite design (CCD) model was employed to optimize the said process } \\
\text { parameters which affect the kinetics of the enzyme- catalysed starch } \\
\text { hydrolysis. The results predicted by the design were found in good agreement } \\
\left(\mathrm{R}^{2}=0.9326\right) \text { with the experimental results indicating the applicability of the } \\
\text { model. The multiple regression analysis showed the individual and } \\
\text { cumulative effect of } \mathrm{pH} \text {, temperature and substrate concentration on the } \\
\text { enzyme activity indicating that the activity increased with the increase of pH } \\
\text { to } 5.0 \text { and temperature to } 65^{\circ} \mathrm{C} \text {. The RSM was successful in determining the } \\
\text { optimum reaction conditions for hydrolysis of barley malt. }\end{array}$ \\
\hline
\end{tabular}

\section{Introduction}

Barley malt contains several prime saccharification enzymes like alpha and beta amylases. The alpha amylases is more thermostable than the beta amylase that is why the former finds potential use in the starch liquefaction generally carried out at $70-90^{\circ} \mathrm{C}$. The optimization of such parameters and the knowledge of the interactions between the variables are important for the determination of the applicability of the enzymes. The conventional methods use variation of one parameter at a time while keeping the others constant, hence the cumulative effect of all the affecting parameters at a time cannot be studied Ranjan et al., (2009). However in the RSM the interaction of two or more variables can be studied simultaneously. The details of the efficiency of RSM over the statistical optimization techniques are available (Ibrahim and Elkhidir, 2011). The RSM approach has been used by several researchers to optimize the process parameters for enhanced production and yield of the target products for industrial applications (Ahmad et al., 2009; Claver et 
al., 2010; Noi et al., 2008 and Omar et al., 2009).

\section{Materials and Methods}

Barley malt, procured from United Breweries, Ludhiana, was ground to coarse powder and mixed with tap water in1:4 ratio. The mixture was incubated in a water bath for saccharification at differnt temperatures, $\mathrm{pH}$ and different substarte concentrations as designed by the software (given below). During the process, presence of starch was examined by mixing $1 \mathrm{ml}$ wort with $0.1 \mathrm{ml}$ standard iodine solution $(0.2 \%$ iodine in $2 \%$ potassium iodide) at different intervals until it tested negative by nonappearance of blue colour. The brew so obtained was filtered through a muslin cloth, allowed to cool and analyzed for its total sugars and reducing sugars ( Dubois et al., 1956 and Miller et al.,1959).

\section{Experimental Design and Statistical Analysis}

A CCD showing maximum and minimum levels of three independent variables i.e. $\mathrm{pH}$, temperature and substrate concentration was followed (Table 1). An outline of the experimental design with the actual levels of the responses is presented in Table 2. The RSM was applied for experimental data using a commercial statistical package, Design- Expert version 8.0.1 (Statease Inc., Minneapolis, MN, USA) for generation of the response surface plots. The results were analyzed by a polynomial quadratic regression method to describe the effects of variables in the models derivetized. Experimental data were fitted to the selected model and regression coefficients obtained. The analysis of variance (ANOVA) tables were generated for each of the response functions. The individual effect of each variable and also the effects of the interaction term in coded levels of variables were determined by the following second order polynomial equation:

$Y=\beta 0+\Sigma i=0$ n $\beta i x i+\sum i=0$ n $\beta n x i+\Sigma i>j ~ n$ $\beta$ ij xi xj

Where $\mathrm{Y}=$ Predicted response, $\beta 0=$ Intercept, $\beta \mathrm{i}=$ Linear coefficient, $\beta \mathrm{n}=$ Squared coefficient, $\beta \mathrm{ij}=$ Interaction coefficient, $x i, x j=$ Independent variables.

The data so obtained was analysed using the above mentioned statistical software and the response surface and the contour plots were constructed to evaluate the optimal value of each variable and the interaction effect of parameters. A central composite factorial was designed with six axial points, six central and eight replicates at the factorial points leading to total 20 experiments. Tables 3 and 5 show the CCD matrix of the independent variables in the form of actual values. The mathematical model relating the yield of total sugars with the independent variables is given below (equation 2):

$$
\begin{aligned}
& \mathrm{Y}=-71.0154+(6.006627) \mathrm{A}+(1.665503) \\
& \mathrm{B}+\quad(0.493036) \quad \mathrm{C}+(-0.02587) \\
& (0.063333) \mathrm{AC}+(-0.0075) \mathrm{BC}+(-0.44605) \\
& \mathrm{A}^{2}+(-0.0111) \mathrm{B}^{2}+(0.0029) \mathrm{C}^{2}
\end{aligned}
$$

The mathematical model relating the yield of reducing sugars with the independent variables is given too (equation 3 ):

$$
\begin{aligned}
& \mathrm{Y}^{*}=-72.0305+(5.659405) \mathrm{A}+(1.685445) \\
& \mathrm{B}+(0.520132) \mathrm{C}+\quad(-0.02642) \mathrm{AB}+ \\
& (0.058556) \mathrm{AC}+(-0.00955) \mathrm{BC}+(-0.4021) \\
& \mathrm{A}^{2}+(-0.01099) \mathrm{B}^{2}+(0.007172) \mathrm{C}^{2}
\end{aligned}
$$

The second order polynomial coefficient for each term of the equation was determined through multiple regression analysis. The results of the regression analysis of the $\mathrm{CCD}$ and of the model fitting in the form of 
ANOVA are given in tables 4 and 6 for total sugars and reducing sugars respectively. The fit of the model was expressed by the coefficient of regression $\mathrm{R}^{2}$, which was found to be 0.995865 and 0.998268 , for total and reducing sugars respectively, explaining $99 \%$ of the variability of the response. The values of adjusted $\mathrm{R}^{2}$ were very high, 0.992143 for total sugars and 0.996709 for reducing sugars, indicating the high level of significance of the model. The significance of each coefficient was determined by $\mathrm{F}$ and $\mathrm{P}$ - values. The larger magnitude of $\mathrm{F}$ - values and smaller magnitude of $P$ values mean the high significance of the corresponding coefficient. The low probability ( $\mathrm{P}$ - value), $<0.05$ indicated the model terms to be significant. On this basis of $\mathrm{A}(\mathrm{pH}), \mathrm{B}$ (temperature) and $\mathrm{C}$ (substrate concentration) were found to be significant. The squared coefficients of $\mathrm{A}^{2}, \mathrm{~B}^{2}$ and $\mathrm{C}^{2}$ were also found to be having a remarkable effect on sugar production. The interaction between all the model terms was significant in both total sugars and reducing sugars analysis. The main objective of the response surface analysis is to efficiently find the optimum value of the process variables. The response surface tool and contour plots were further studied to find the optimum values of three variables for maximum sugar production. A wide variation of the sugar concentration observed in this study shows the importance of the optimization of the fermentation medium in the development of the fermentation process. Based on this concept, a trial on saccharification of malt was laid which based on the optimized conditions of $\mathrm{pH}$, temperature and substrate concentration.

\section{Results and Discussion}

Even though the enzymatic reactions are emerging as alternative processes over inorganic catalytic reactions, the main drawbacks such as high cost associated with the production and the purification of enzymes and their wasteful interaction during the reaction limits their application. Therefore, the main strategy used in the enzymatic industrial processes is the proper experimental design and optimization of procedures for the maximum economy. The RSM has been widely applied for optimization of the enzymatic processes as well as other catalytic studies (Lee et al., 2003 and Schepers et al., 2003). It is an efficient statistical technique for optimization of the multiple variables in order to predict the best performance conditions while performing the minimum number of experiments. These designs are used to find the improved or optimal process settings, troubleshoot process problems and weak points and make a product or process more robust against external or non controllable influences (Kunamneni and Singh ,2005; Silva et al., 2006). It is observed from the results in table 3 that the value of constant was 7.75 with the $F$ value 124.01 and the $\mathrm{P}$ value $<0.0001$. Clearly value of the constant is significant because of the high F- value and the low Pvalue. It is also represented that the value of the constant does not depend on the linear term, square term as well as interaction term of the variables. It may be further seen in table 3 that the linear terms; $\mathrm{pH}$, temperature and the substrate concentration i.e. 45.66, 18.42 and 845.12 respectively were significant because of the low $\mathrm{P}(<0.005)$ and high $\mathrm{F}$ values. The quadratic terms of $\mathrm{pH}$, temperature and substrate concentration were also significant with $\mathrm{F}$ values 77.02 , 94.16 and 2.02 respectively. Thus initially, the enzyme activity will increase corresponding with the increase in $\mathrm{pH}$ until it attains the maximum. Thereafter enzyme activity will decrease with the increase of $\mathrm{pH}$. Similarly the linear term temperature was also found significant because of low P- 
Int.J.Curr.Res.Aca.Rev.2016 4(1): 146-154

value $(<0.05)$ and very high $\mathrm{F}$ value $(18.42)$ .The quadratic term of the temperature was also significant as the $\mathrm{P}$ - value was 0.004 but the F-value was 94.16 which is more than the linear $\mathrm{F}$ value 18.42. Linear term substrate concentration was also found significant because of low P-value, $<0.0001$ and very high F- value 845.12.

Table.1 Coded and Assigned Concentrations of Variables Of Different Levels of the Central Composite Design Central Composite Design

\begin{tabular}{|l|c|c|c|}
\hline \multirow{2}{*}{$\begin{array}{l}\text { Independent } \\
\text { variables }\end{array}$} & \multicolumn{3}{|c|}{ Levels } \\
\cline { 2 - 4 } & $\mathbf{- 1}$ & $\mathbf{0}$ & $\mathbf{+ 1}$ \\
\hline $\mathrm{pH}$ & 4 & 5.5 & 7 \\
\hline Temperature $\left({ }^{\circ} \mathrm{C}\right)$ & 55 & 65.0 & 75 \\
\hline $\begin{array}{l}\text { Substrate conc. } \\
(\%)\end{array}$ & 15 & 20.0 & 25 \\
\hline
\end{tabular}

Table.2 Central Composite Design of Independent Variables with the Response of Total and Reducing Sugars

\begin{tabular}{|c|c|c|c|c|c|}
\hline Run & pH & Temp. $\left({ }^{\mathbf{0}} \mathbf{C}\right)$ & $\begin{array}{c}\text { Substrate } \\
\text { conc. }(\boldsymbol{\%})\end{array}$ & $\begin{array}{c}\text { Total sugars } \\
(\mathbf{\%}) \mathbf{0}\end{array}$ & $\begin{array}{c}\text { Reducing } \\
\text { sugars (\%) }\end{array}$ \\
\hline 1 & 5.50 & 48.10 & 17.50 & 5.20 & 4.70 \\
\hline 2 & 5.50 & 65.00 & 17.50 & 7.50 & 6.70 \\
\hline 3 & 4.00 & 75.00 & 10.00 & 2.50 & 1.70 \\
\hline 4 & 4.00 & 55.00 & 10.00 & 2.20 & 1.25 \\
\hline 5 & 5.50 & 65.00 & 4.86 & 2.40 & 1.70 \\
\hline 6 & 4.00 & 75.00 & 25.00 & 7.20 & 6.50 \\
\hline 7 & 5.50 & 65.00 & 17.50 & 8.80 & 7.70 \\
\hline 8 & 5.50 & 81.80 & 17.50 & 3.90 & 2.70 \\
\hline 9 & 4.00 & 55.00 & 25.00 & 8.30 & 7.50 \\
\hline 10 & 8.02 & 65.00 & 17.50 & 6.20 & 5.80 \\
\hline 11 & 5.50 & 65.00 & 17.50 & 7.50 & 6.20 \\
\hline 12 & 7.00 & 75.00 & 25.00 & 9.00 & 7.80 \\
\hline 13 & 5.50 & 65.00 & 17.50 & 7.50 & 6.70 \\
\hline 14 & 2.97 & 65.00 & 17.50 & 3.50 & 2.70 \\
\hline 15 & 5.50 & 65.00 & 17.50 & 7.50 & 6.20 \\
\hline 16 & 5.50 & 65.00 & 17.50 & 7.70 & 6.50 \\
\hline 17 & 7.00 & 55.00 & 25.00 & 12.50 & 11.80 \\
\hline 18 & 5.50 & 65.00 & 30.10 & 13.90 & 14.20 \\
\hline 19 & 7.00 & 55.00 & 10.00 & 2.70 & 1.50 \\
\hline 20 & 7.00 & 75.00 & 10.00 & 2.30 & 1.78 \\
\hline & & & & & \\
\hline
\end{tabular}


Int.J.Curr.Res.Aca.Rev.2016 4(1): 146-154

Table.3 Estimated Regression Coefficient of Total Sugars in Saccharifiction of Barley Malt vs ph, Temperature and Substrate Conc. in Coded Values

\begin{tabular}{|l|c|c|c|c|}
\hline Source & Coefficient & SE coefficient & F - value & P- value \\
\hline Intercept & 7.75 & 0.18 & 124.01 & $<0.0001$ \\
\hline $\mathrm{A}$ & 0.79 & 0.12 & 45.66 & $<0.0001$ \\
\hline $\mathrm{B}$ & 0.50 & 0.12 & 18.42 & $<0.0010$ \\
\hline $\mathrm{C}$ & 3.42 & 0.12 & 845.12 & $<0.0001$ \\
\hline $\mathrm{AB}$ & -0.39 & 0.15 & 6.37 & $<0.0010$ \\
\hline $\mathrm{AC}$ & 0.71 & 0.15 & 21.55 & $<0.0001$ \\
\hline $\mathrm{BC}$ & -0.56 & 0.15 & 13.43 & 0.0030 \\
\hline $\mathrm{A}^{2}$ & -1.00 & 0.11 & 77.02 & 0.0010 \\
\hline $\mathrm{B}^{2}$ & -1.11 & 0.11 & 94.16 & 0.0040 \\
\hline $\mathrm{C}^{2}$ & 0.16 & 0.11 & 2.02 & $<0.0001$ \\
\hline $\mathrm{R}^{2}$ & &
\end{tabular}

$\mathrm{R}^{2}=99.11 \%, \mathrm{R}^{2}$ (pred) $=96.92 \mathrm{R}^{2}$ (adjusted) $=98.3 \%$

Table.4 Analysis of Variance for Total Sugars in Saccharification of Barley Malt

\begin{tabular}{|l|c|c|c|c|}
\hline Source & Df & Seq. SS & F- value & P-value \\
\hline Regression & 9 & 210.36 & 124.01 & $<0.0001$ \\
\hline Linear & 3 & 171.36 & 22.36 & $<0.0001$ \\
\hline 2F1 & 3 & 7.79 & 1.02 & 0.4102 \\
\hline Quadratic & 3 & 31.20 & 55.18 & $<0.0001$ \\
\hline RE & 6 & 1.39 & & \\
\hline Total & 20 & 1035.29 & & \\
\hline
\end{tabular}

Table.5 Estimated Regression Coefficient of Reducing Sugars in Saccharifiction of Barley Malt vs ph, Temperature and Substrate Conc. in Coded Values

\begin{tabular}{|l|c|c|c|c|}
\hline Source & Coefficient & SE coefficient & F - value & P- value \\
\hline Intercept & 6.67 & 0.23 & 80.12 & $<0.0001$ \\
\hline $\mathrm{A}$ & 0.82 & 0.15 & 29.10 & $<0.0001$ \\
\hline $\mathrm{B}$ & -0.56 & 0.15 & 13.66 & $<0.0010$ \\
\hline $\mathrm{C}$ & 3.54 & 0.15 & 548.83 & $<0.0001$ \\
\hline $\mathrm{AB}$ & -0.40 & 0.20 & 4.02 & $<0.0010$ \\
\hline $\mathrm{AC}$ & 0.66 & 0.20 & 11.11 & 0.0076 \\
\hline $\mathrm{BC}$ & -0.72 & 0.20 & 13.14 & 0.0040 \\
\hline $\mathrm{A}^{2}$ & -0.90 & 0.15 & 37.75 & 0.0001 \\
\hline $\mathrm{B}^{2}$ & -1.10 & 0.15 & 55.73 & $<0.0001$ \\
\hline $\mathrm{C}^{2}$ & 0.40 & 0.15 & 7.51 & 0.0200 \\
\hline
\end{tabular}

$\mathrm{R}^{2}=99.82 \%, \mathrm{R}^{2}$ (pred) $=96.92 \%, \mathrm{R}^{2}$ (adjusted $=98.31 \%$

(values $<0.05$ are significant) 
Int.J.Curr.Res.Aca.Rev.2016 4(1): 146-154

Table.6 Analysis of Variance for Reducing Sugars in Saccharification of Barley Malt

\begin{tabular}{|l|c|r|r|r|}
\hline Source & Df & Seq. SS & F- value & P- value \\
\hline Regression & 9 & 225.300 & 80.12 & $<0.0001$ \\
\hline Linear & 3 & 184.840 & 22.61 & $<0.0001$ \\
\hline 2F1 & 3 & 8.830 & 1.10 & 0.3839 \\
\hline Quadratic & 3 & 31.640 & 33.75 & $<0.0001$ \\
\hline RE & 6 & 1.710 & & \\
\hline Total & 20 & 851.490 & & \\
\hline
\end{tabular}

( values $<0.05$ are significant)

Fig.1 Coutour Graph Showing the Total Sugars Released at Substrate Concentration of 17.5\%

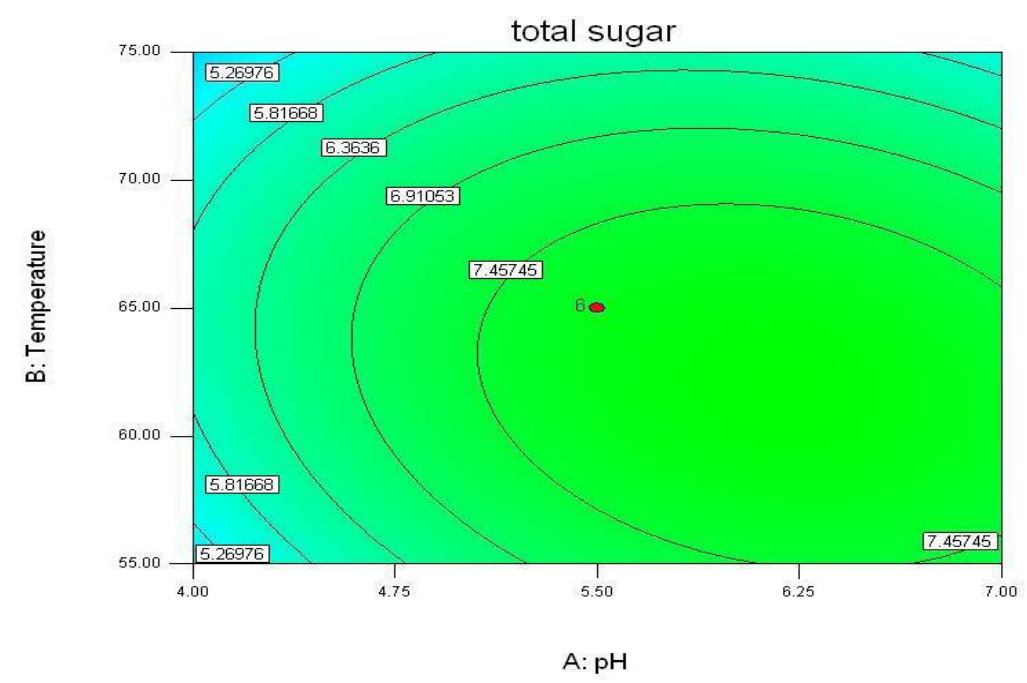

Fig.2 Coutour Graph Showing the Reducing Sugars Released at Substrate Concentration of $17.5 \%$

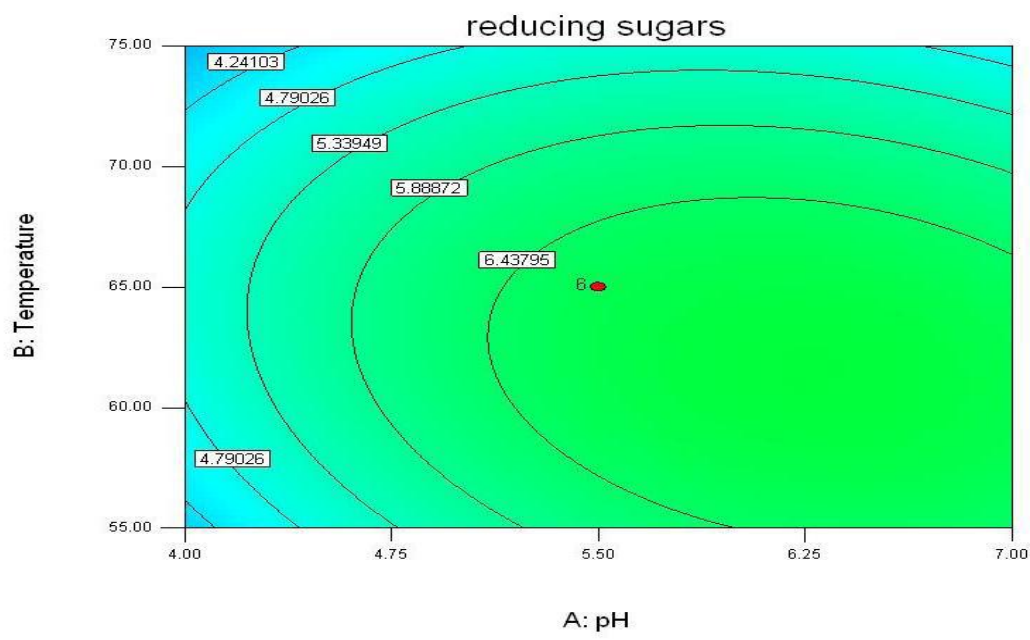


Int.J.Curr.Res.Aca.Rev.2016 4(1): 146-154

Table.7 Saccharification Parameters of Malt

\begin{tabular}{|l|l|}
\hline $\mathrm{pH}$ & 5.5 \\
Temperature (C) & 55 \\
Substrate concentration ( & 17.5 \\
$\%$ ) & 50 \\
Total time ( min.) & 250 \\
Volume of wort (ml) & 10.5 \\
Total sugars (\%) & 8.5 \\
Reducing sugars (\%) & \\
\hline
\end{tabular}

Table.8 Change in Sugars During Saccharification of Malt

\begin{tabular}{|l|l|l|}
\hline $\begin{array}{l}\text { Time } \\
(\mathrm{min})\end{array}$ & $\begin{array}{l}\text { Total sugars } \\
(\%)\end{array}$ & $\begin{array}{l}\text { Reducing } \\
\text { sugars }(\%)\end{array}$ \\
\hline 10 & 1.4 & 0.82 \\
20 & 3.8 & 3.0 \\
30 & 6.5 & 5.78 \\
40 & 8.7 & 7.51 \\
50 & 10.5 & 8.5 \\
60 & 10.5 & 8.5 \\
\hline
\end{tabular}

Similarly, the quadratic term of the substrate concentration is also significant as the Pvalue is $<0.001$ with F-value 2.02 . But in interaction of substrate concentration with $\mathrm{pH}$ and temperature, the low $\mathrm{P}$-values < 0.0001 and 0.003 with high $F$ values 21.55 and 13.43 indicated that the substrate concentration alone does not have the direct influence on the saccharification but with other two variables it plays a significant role in the optimization process. It was also observed that linear and interaction terms of $\mathrm{pH}$ and substrate concentration and quadratic term of substrate conc. were having the positive values of the regression coefficient.

This is because of the synergistic effect of $\mathrm{pH}$ and substrate concentration, hence percentage of the total sugars increases with increase in $\mathrm{pH}$ and substrate concentration. The interaction terms $\mathrm{pH}$-temperature and temperature- substrate concentration and quadratic term of $\mathrm{pH}$ and temperature have the negative value of regression coefficient which indicates the antagonistic effect of quadratic terms of temperature and $\mathrm{pH}$. This means that at high temperature and $\mathrm{pH}$, the rate of total sugars released in the wort decreases. Analysis of variance (ANOVA) was utilized for statistical testing of the model in the form of linear, squared and the interaction terms (Table 4 and table 6). The P-value $<0.0001$ both for linear and quadratic terms confirms the applicability of the model. It was found from the results that the P-values for all the variables were lower than 0.05 which shows the significant correlation of regression with the response variation in the interpretation of regression analysis. Significant high F - values for total and reducing sugars i.e. 124.01 and 80.12 respectively, indicated that the second order polynomial model response was sufficient to 
show the actual relationship between the response i.e sugars (both total and reducing sugars) and the model process variables namely $\mathrm{pH}$, temperature and substrate concentration.

The main effect plot was drawn to visualize the effects of each variable and it is shown in Fig 1and 2 for $\mathrm{pH}$ and temperature. It show that the response was greater at $\mathrm{pH} 5.5$ while it was less than average at $\mathrm{pH}$ i.e, 4.0, $4.5,5.0,6.0,6.5,7.0$. At the initial temperatures such as 50,55 and $60^{\circ} \mathrm{C}$ the response were below the mean value whereas for rest of the temperatures, the response was above the mean value. The mean responses were found to be maximum affected by higher temperatures, 70,75 and $80^{\circ} \mathrm{C}$. The maximum value was achieved at $65^{\circ} \mathrm{C}$.This type of main effect plot using statistical design is described to show the effect of the parameters i.e. force, and speed in the output voltage of the nanogenerators (Schepers et al., 2003 and Song et al., 2010).

The coutour graphs (Fig.1 and 2) give the better understanding about the influence of the variable and their interaction on the response as compared to the $3 \mathrm{D}$ surface plot. The contour plots representing the combined effect of $\mathrm{pH}$ and temperature on the enzyme activity explains that the activity increases with the increase in temperature. However the behavior was different with $\mathrm{pH}$ because the enzyme activity was found to increase from $\mathrm{pH} 4.5$ to 5.5 but decreased $\mathrm{pH}$ above 5.5 upto 9.0 . The maximum enzyme activity was found at $\mathrm{pH} 5.5$ and temperature $65^{\circ} \mathrm{C}$. Based on the RSM determined response, saccharification studies were carried out at $\mathrm{pH}$ 5.5, temperature $65^{\circ} \mathrm{C}$ and $17.5 \%$ substrate concentration. The results given in tables 7 and 8 indicate that total sugars increased from 1.4 to $10.5 \%$ at the end of saccahrification. Likewise reducing sugars increased from initial 0.82 to $8.5 \%$ until the starch tested negative in the wort.

\section{Conclusion}

The RSM model has been predicted by the statistical and graphical technique where two level - two factor $\left(2^{2}\right)$ is used for the experimental results. The RSM has been successfully applied to determine the optimum reaction conditions (temperature $65^{\circ} \mathrm{C}$ and $\mathrm{pH} 5.5$ and substrate concentration $17.5 \%$ ) for starch hydrolysis by inherent amylases of the barley malt. The predicted results are close to the experimental values indicating the suitability of the model. Hence the same has been applied for saccharification of the $250 \mathrm{ml}$ barley malt securing $10.5 \%$ and $8.5 \%$ total and reducing sugars respectively in $50 \mathrm{~min}$.

\section{References}

Ahmad, A., Anjum, F. M., Zahoor, T. and Nawaz, H.: (2009), Pak J Nutr. 8,1486-1492.

Claver, I. P., Zhang, H., Kexue, Li. Z. and Zhou, H. :( 2010), Pak J Nutr. 9,336342.

Dubois, M., Gill, S. K. A., Hamilton, J. K., Roberts, P.A. and Smith, F.: (1956), Anal Chem. 28, 350-356.

Ibrahim, H. M. and Elkhidir, E.: (2011), Applied Sci Res. 6, 121-129.

Kunamneni, A. and Singh, S.: (2005), Biochem Eng J. 27, 179-190.

Lee, H., Song, M. and Hwang, S.: (2003), Process Biochem. 38, 1685-1693.

Miller, G. L.: (1959), Anal Chem. 31,426428.

Noi, Ai., Suraini, A.A., Norjahan, A., Osman, H. and Abdul, K.M. I.: (2008), Biotechnology.10-18.

Omar, K. A., Shah, X., Zou, X., Song, Z. and Wang, X.: (2009), Pak J Nutr. 8, 316-324. 
Ranjan, D., Talat, M. and Hasan, S. H.: (2009), J Hazard Mat. 166, 10501059.

Ravikumar, K., Krishnan, S., Ramalingam, S. and Balu, K.: (2007), Dyes Pigments. 72, 66-74.

Schepers, A. W., Thibault, J. and Lacroix, C.: (2003), Enzyme Microbiol Technol. 30, 176-186.
Silva, C. J. S. M., Gubitz, G., and Cavaco, Paulo A.: (2006), J Chem Technol Biotech. 81, 8-16.

Song, J., Xie, H., Wu, W., Joseph, V. R., Wu, C. F. J., Wang, Z. L.: (2010), Nano Res. 3,613-619.

\section{How to cite this article:}

Naveet and Phutela, R.P. 2016. Optimizing Saccharification of Barley Malt by Response Surface Methodology. Int.J.Curr.Res.Aca.Rev. 4(1): 146-154 doi: http://dx.doi.org/10.20546/ijcrar.2016.401.013 